\title{
Analysis and Interpretation of Genocide Related Terms
}

\author{
Naira Gasparyan \\ Yerevan State University
}

\begin{abstract}
The present article seeks to establish the cognitive value and the communicative message of genocide related terms with the account of the extra-linguistic factors. Terms like slaughter, massacre, ethnic cleansing, physical annihilation, killings, deportations are used to present and discuss both pro-Turkish attitudes of and neutral or pro-Armenian standpoints of great humanists and friends of Armenians. Still another intent of ours is to show that the terms genocide and democide which realize a specifically highlighted cognitive function, are the most appropriate ones to best define the disastrous events of 1915 on the territory of West (Turkish) Armenia.
\end{abstract}

Key words: Linguocognitive, Armenian genocide, deportations, democide, synonyms.

\section{Introduction}

History knows many terms equivalent or synonymous to genocide -among them ethnic cleansing, massacres, slaughters, annihilations, race murder, killings, deportations, holocaust and so on. Yet every nation who happened to have faced such a disaster, called the inhumane deed in their own national language: thus appeared the Mets Eghern, Seifo, Shoah...

To define the massacres of the Armenians in 1915 in West (Turkish) Armenia in Ottoman Turkey, in other words - what is known in history as Mets Eghern, we need to investigate, the correlation between various synonymous genocide related terms that appear in official and legal international documents.

The term genocide is known to belong to the sphere of history, but as Antoine Laurent Lavoisier wrote in 1789:

It is impossible to dissociate language from science or science from language, because every natural or social science always involves three things: the sequence of phenomena on which the science is based; the abstract concepts which call these phenomena to mind; and the words in which the concepts are expressed.

(Cohen 2011: Chapter18.1) 
Experts of various fields - lawyers, psychologists, sociologists, experts of Turkish, Armenian, Oriental studies, philologists, historians - have referred to genocide issues taking efforts to elucidate the problem at different angles. It is well-known that anti-Armenian and pro-Turkish public and political figures worked hard to hamper the solution of the everlasting problem. According to the New York Times, February 1915 issue, Signor Filippo Media, MP of Italian Chamber of Deputies, while discussing some aspects of the Armenian situation wrote in an article that the Armenian question could have long been settled if it had not been for Disraeli and his assistant Salisbury (The Armenian Genocide - News Accounts from the American Press: 1915-1922).

Modern Turkey succeeded the Ottoman Empire in 1923 and vehemently denies that a genocide took place. Moreover, on international arena the term deportation is used by Turkish officials to openly misinterpret the events in Ottoman Turkey in 1915. It has resisted calls in recent years by scholars, countries and international organizations to acknowledge the crime. The Armenian genocide is the second most-studied case of genocide after the Holocaust. Lemkin coined genocide with the Armenian genocide in mind.

\section{National Identity as Reason of Mass Killings of Armenians: Analysis of Standpoints}

E.T. Lawrence, known as Lawrence of Arabia, writes in his documentary Seven Pillars of Wisdom (1922) that Armenians were declared state prisoners, that is enemies of Turkey. Lawrence's keen observations establish that:

The Young Turks had killed the Armenians, not because they were Christians, but because they were Armenians; and for the same reason they herded Arab Moslims and Arab Christians into the same prison, and hanged them together on the same scaffold.

(Lawrence 1922: Chapter IV)

From V. Dadryan's book we learn that Major General Otto von Lossow, acting military attaché and head of the German Military Plenipotentiary in the Ottoman Empire, spoke to Ottoman intentions in a conference held in Batumi in 1918: 
[...] The aim of Turkish policy is, as I have reiterated, the taking of possession of Armenian districts and the extermination of the Armenians. Talaat's government wants to destroy all Armenians, not just in Turkey but also outside Turkey. On the basis of all the reports and news coming to me here in Tiflis there hardly can be any doubt that the Turks systematically are aiming at the extermination of the few hundred thousand Armenians whom they left alive until now.

(Dadryan 1995:349)

It becomes obvious from the passage above that the Major General Otto von Lossow's speech includes the collocation extermination of Armenians as s key to define the aims of the Turks. What is more astounding is that Talaat's government wants to destroy all Armenians, not just in Turkey. Dadryan sparingly shows that initiating killings of Armenians Turkish authorities aimed at confiscating all their property, including land, livestock, and homes. On 13 September 1915, the Ottoman parliament passed the Temporary Law of Expropriation and Confiscation since the application of the previously existing Abandoned Properties law, as Ahmed Riza Bey protested, would not be justified - for the Armenians, the proprietors, did not abandon their properties voluntarily; they were forcibly, compulsorily removed from their domiciles and exiled. (Dadryan 1995:223-224).

In the example above we find the message of the collocation forcibly, compulsorily removed to be overlapping with that of deported.

Edgar T.A. Wigram's observations confirm that the majority of the Armenians were inoffensive cultivators, they included a considerable number of intelligent and capable men and only a small percentage were active political propagandists, who continued to work persistently to overthrow the regime. Wigram stresses that

[...] under equal political conditions the Armenians would secure dominance. The Turks would never cope with the Armenians in cleverness but they were always able to initiate physical force against unarmed Armenians and succeed.

(Wigram 1922:19)

There is a lot of factual writing witnessing that Armenians were to be abolished because of their national identity, which aroused much jealousy since they were witty, creative, intelligent, inventive, successful and easily adapted to any situation 
continuing to show interests in education, and saving money for their children's education (Steffens 1919).

To establish which genocide related terms - race murder, ethnic cleansing, physical annihilation, slaughters, massacres, killings, deportations and so on - best describe the massacres of Armenians in 1915 we need to initiate further investigation of the linguistic material of some important international legal documents which will provide us with the required information.

Let us adduce a passage from Noel and Harold Buxtons' documentary book Travel and Politics in Armenia which actually presents the accounts of the great humanists and outstanding public figures written for the British Parliament after their long journey in West and East Armenia which they call correspondingly Turkish Armenia and Russian Armenia. They write:

Yet it remains true, and I have never heard the statement seriously challenged, that there are no massacres in Turkey except when ordered by the Government. The massacres of 1895-96, the massacres at Van, March 1908; the massacres at Adana and in Cilicia, 1909 have all been by the consent of authority.

(Buxton and Buxton 1914:43)

In 1916, on the request of the British Parliament Lord James Bryce, great humanist and lawyer, together with historian Arnold Toynbee published a book which is known in the history of genocides as The Blue Book, also known as The treatment of Armenians in the Ottoman Empire (Bryce 1916). It covers statements by eyewitnesses, the correspondence and memoirs of officials including refugees and foreign dignitaries from Germany, Italy, the Netherlands, Sweden, and Switzerland - as well as newspaper articles - about the Armenian genocide between the years of 1915 and 1916. The book is qualified by Michelle Tusan, Professor of History from Nevada University as follows:

No other document made a clearer case for genocide against the Armenians than the one published by Bryce in Great Britain in 1916. The Treatment of Armenians in the Ottoman Empire: 1915-16 contained compelling letters, reports, and individual accounts from over one hundred sources that chronicled Turkish atrocities.

(Tusan 2015:35) 
Issued as a Parliamentary Blue Book the 733-page volume was the most complete set of testimonies on the massacre of Armenian civilians that started in the spring of 1915. M. Tusan is quite right to mention that Bryce's training as a lawyer and Toynbee's training as a historian led to the organization of the Blue Book, which was intended as a document that would make the case in the international arena against Turkey for committing crimes against humanity and violating the laws of war during World War I (Tusan 2015:41).

Tusan qualifies The Blue Book as an atrocity chronicle. There cannot be found a better and to the point metaphoric epithet to define the disaster that Armenians experienced in 1915. A close consideration of the documentary writing on The Armenian Genocide and the collection of documents in The Blue Book, in particular, comes to confirm that what happened to the Armenians in West Armenia, which was part of Turkey, was a well-organized and well-calculated mass murder on the ethnic background. It is hardly surprising that Raphael Lemkin referred to Bryce's The Blue Book as a source when, using the Armenian case, he set out to define what he first identified as genocide or race murder (Tusan 2015:41).

In another investigation, carried out by the Turkish intellectual Taner Akcam, we come across a different collocation which is synonymous to genocide. Akcam defines assimilation as an inseparable part of the Armenian deportations and annihilation. Making his speech he focused his attention on the fact that

\section{[...] There is a relationship between assimilation and physical} destruction. When faced with a situation wherein they believed that the policy of assimilation constituted a danger, they put an end to it and turned toward the choice of physical annihilation. At a clear stage of physical annihilation, in situations where they believed that those who remained behind were not problematic from the point of view of governability, they again favored assimilation policies. Thus, balance between assimilation and physical annihilation was of key importance throughout deportation.

(Akcam 2010:57)

Taner Akcam's discussion of physical annihilation goes hand in hand with the concept of assimilation since the two terms appear to be the continuation of each other, since when one of them becomes weaker the other one becomes stronger. It 
means that they cannot be separated from each other and must be viewed as an expression of genocide.

Further research establishes that in literature and in international conventions, in particular, the concept of genocide has been defined as intentional killing by government of people because of their race, religion, ethnicity, or other indelible group membership. While killing people because of their politics or for political reasons has been explicitly excluded from the international Genocide Convention, some scholars nonetheless have included such killing in their study of genocide, while some others have extended the definition of genocide to cover any mass murder by government. R.J. Rummel, an outstanding genocide scholar, offers to use the term democide for defining the killing by states. Rummel, as a keen investigator, notices that genocide may or may not include government murder. It may refer to wholly or partially eliminating some group, or involve psychological damage. If it includes government murder, it may mean all such murder or just some. In his work he thoroughly discusses the overlapping parts of the meanings of genocide and democide (Rummel 1994).

Rummel introduced the term democide to clearly point out that this very term democide includes all the aspects of genocide. He adds that the importance of the concept of government murder in certain cases, like the Armenian Genocide and the Holocast of the Jews, should not be ignored since the concept genocide hardly covers the variety and extent of ruthless murder carried out by governments. Rummel does not hesitate to declare:

Where the political elite can command all, where they can act arbitrarily, where they can kill as they so whim, they are most likely to commit democide. Where the elite are checked by countervailing power, where they are restrained and held to account for their actions, where they must answer to the very people they might murder, they are least likely to commit democide.

(Rummel 1997:367)

Rummel suggests using the concept democide to cover all such murder (the intentional killing by government of people because of their race, religion, ethnicity, or other indelible group membership), any kind of cold-blooded deliberate government killings extending beyond genocide defined as starving civilians to death by a blockade, assassinating supposed sympathizers of anti- 
government guerrillas, purposely creating a famine, executing prisoners of war, shooting political opponents, or murder by quota (Rummel 1994).

\section{Analysis of Genocide Terms in American and British Newspaper Headlines (1915-1923)}

The research reveals that no government can ever happen to be unaware of what is happening on the territory of the state. In regard with this, we find it important to adduce some newspaper headings from American and British Archives of the period of 1915-1923 which have found their place in Richard Kloian's documentary book. The book includes articles from 1915 to 1923 published by outstanding American and British newspapers on the 1915 atrocities and slaughters in West (Turkish) Armenia. Only the headlines from the papers are enough to understand that the events were organized on the state level. Let us adduce some headlines from American and British newspapers and analyze them.

From American Archives:

1. Report of Allied warning to the Ottoman government to stop the massacres of Armenians. May 29, 1915;

2. Secretary of State Robert Lansing's response to news that Ottoman Turkey is pursuing a policy of genocide against the Armenians. July 16, 1915;

3. Report that Ottoman Turkey is seeking to exterminate the Armenian nation. July 16, 1915;

4. Report from a German missionary on the massacre of Armenians from Erzerum, July 31, 1915;

From British Archives:

1. Memorandum by the Committee of Union and Progress outlining the strategy for implementing the Armenian Genocide. 1914-1915;

2. Report on the massacre of Armenians in Cilicia under French administration. March, 1920;

3. First-hand account by a Turkish Army officer on the deportation of Armenians from Trebizond and Erzerum, December 26, 1916

(The Armenian Genocide - News Accounts from the American Press: 19151922)

It is beyond doubt that newspaper headlines are rhematic - they are carriers of the communicative intent. In other words, rhema passes on the novel information with the help of the already known thema. Moreover, all the mentioned headlines contain language units which belong to the same thematic group - mass killings, or 
genocide of Armenians. Only in the last example where the term deportation is used, there is no direct or explicit hint on killings of Armenians. To find the necessary information we can have a look at the article which follows the headline. Here we find the following lines:

In July an order came to deport to the interior all the Armenians in the Vilayet of Trabizond. Being a member of Court Martial I knew that deportations meant massacres.

(The Armenian Genocide - News Accounts from the American Press: 1915-1922)

The Turkish officer's report published by a British newspaper leaves no place for hesitation that deportations meant massacres.

\section{Analysis of Genocide Related Terms}

There is no doubt that all of the mentioned terms - Mets Yeghern, Ethnic cleansing, Deportation, Slaughtering, Massacres, Genocide, Democide - refer to killings of people. The only ones which do not directly mean killings explicitly are deportation and ethnic cleansing which actually mean one and the same thing and implicitly indicate mass killings. The verb deport is defined by the Oxford Advanced Learner's Dictionary as to force someone to leave a country, usually because they have no legal right to be there (Hornby 2006:392). The linguistic investigation establishes deportation to be linguistically equal with ethnic cleansing which the same dictionary defines as the policy of forcing the people of a particular race or religion to leave an area or a country (Hornby 2006:498). It is obvious that ethnic cleansing is stylistically more expressive and impressive and its cognitive function is comparatively more highlighted than those of deportation. It can be inferred that when these terms are used to define policies about millions or even several thousands of people who are left without clothes, food, water, inhumane conditions, anyhow, the first thought that comes to one's mind is connected with torturing and indirect killings. To be on the safe side the proTurkish prefer to use the term deportation which also gives a hint that everything was well-planned, even the choice of the words was sophisticated.

Lord Bryce shared T.E. Lawrence's and R.J. Rummel's standpoints on the massacres of 1915 - they had political rather than religious origins: 
There was no Moslem passion against the Armenian Christians. All was done by the will of the Government, and done not from any religious fanaticism, but simply because they wished, for reasons purely political, to get rid of a non-Moslem element which impaired the homogeneity of the Empire, and constituted an element that might not always submit to oppression.

(Bryce 1915)

The use of the collocations no Moslem passion, not from any religious fanaticism for reasons purely political confirms the fact that religion was not the primary reason of the mass killings of the Armenians. The Blue Book presented the motivation for the massacres as rooted in the politics of the empire and the Ottoman attempt to preserve its empire was what motivated the killings. The Blue Book charted the systematic nature of the massacres by the government, documenting the presence of concurrent massacres throughout the whole of Anatolia. The Blue Book opened the hidden truth and it caused much excitement among the Turkish authorities since the documentary proof was more than bearable.

Now we would like to adduce R.J. Rummel's standpoint on the above mentioned terms. He defines genocide as something which does not necessarily mean the immediate destruction of a nation, except when accomplished by mass killings of all members of a nation. It is intended rather to signify a coordinated plan of different actions aiming at the destruction of essential foundations of the life of national groups, with the aim of annihilating the groups themselves. Discussing the concepts of genocide, politicide, mass murder or massacre, and terror Rummel mentions that they overlap and are sometimes used interchangeably. As far as the concept democide is concerned, he stresses that it is limited neither to the killing component of genocide, nor to politicide, mass murder, massacre or terror (Rummel 1994).

It includes them all and also what they exclude, as long as such killing is a purposive act, policy, process, or institution of government. In detail, democide is any actions by government.

(Rummel 1994:Chapter 2) 
Thus, the analysis establishes that to define the Turkish Genocide of Armenians in 1915 the most suitable appropriate synonym is no other term than democide.

\section{Conclusion}

The investigation establishes that although all the above analyzed terms either explicitly or implicitly overlap with the term genocide, and can be used as synonyms to it, none of them indicates either directly or indirectly that the massacres which took place in the West (Turkish) Armenia in 1915, were elaborately organized and, what is more important, organized on the level of the government and state. In other words, through the analysis of the linguistic material we can conclude that the policy of the Ottoman Turkish government was directed towards destroying and annihilation of both the Armenian gene and the Armenian nation. Thus, in this respect, those events of mass killings, deportations and annihilations on ethnic background should be viewed not just as acts of genocide but as those of democide, because as R.J. Rummel mentions democide is any murder by government including the form of genocide.

\section{Sources of Data:}

1. Akçam, T. (2010) Assimilation and The Armenian Genocide. // Proceedings of International Conference, December 14-15, 2010, pp. 51-63.

2. Bryce, J. (1916) The Blue Book. The Treatment of Armenians in the Ottoman Empire. London, Printed under the authority of his Majesty's stationery office. Available at: <http://net.lib.byu.edu/ rdh7/ wwi/1915/bryce/a00tc.htm $>$ [Accessed October 2016].

3. Bryce, J. (1915) Report into the Armenian Massacre ... - First World. Available at: <War.comWww.firstworldwar.com/source/brycereport_armenia.htm $>$ [Accessed November 2016].

4. Cohen, L. et al (2011) Classical, Semi-classical and Quantum Noise. Available at: <https://books.google.am/books?isbn=1441966234.Chapter18.1 $>$ [Accessed September 2016].

5. Dadrian, V.N. (1995) The History of the Armenian Genocide: Ethnic Conflict from the Balkans to Anatolia to the Caucasus. Oxford: Berghahn Books.

6. Hornby, A.S. (2006) Oxford Advanced Learner's Dictionary of Current English. $7^{\text {th }}$ edition. Oxford: OUP.

7. Lawrence, E.T. (1922) Seven Pillars of Wisdom. UK: Private Edition. 
8. Rummel, R.J (1994) Democide vs Genocide. Which is What? Available at: $<$ https://www.hawaii.edu/powerkills/GENOCIDE.HTM $>$ [Accessed October 2016].

9. Rummel, R.J. (1994) Death by Government. Available at: $<$ https://www.hawaii.edu/powerkills/NOTE1.HTM > [Accessed September 2016].

10. Rummel, R.J. (1994) Death by Government. Available at: $<$ https://www.hawaii.edu/powerkills/DBG.CHAP2.HTM $>$ [Accessed September 2016].

11. Steffens, L. Armenians are Impossible: Interview with Lawrence of Arabia in 1919. Available at: <armenians-1915.blogspot.com/2008/.../2471-armeniansare-impossible-interview.htm...> [Accessed September 2016].

12. The Crime of Genocide: Prevention, Condemnation and Elimination of Consequences. Available at: <www.mfa.am/u_files/file/the_crime_of_ genocide.pdf $>$ [Accessed December 2016].

13. The Armenian Genocide - News Accounts from the American Press: 19151922 (1980). / Compiled by R. Kloian. Available at: <http://www.cilicia.com/ armo10c-ar191602.html $>$ [Accessed October 2016].

14. (1985) The Armenian Genocide - News Accounts from the American Press: 1915-1922. / Compiled by R. Kloian. Available at: <http://www.armeniangenocide.org/br-12-26-16-text.html $>$ [Accessed October 2016].

15. Tusan, M. (2015) James Bryce's Blue Book as Evidence. // Journal of Levantine Studies. Available at: $<$ www.levantine-journal.org/James+Bryce's +Blue+Book+ as+Evidence /pp. 35-50> [Accessed September 2016].

16. Wigram, E.T.A. (1922) Cradle of Mankind. Life in Eastern Kurdistan. Available at: $<$ https://docs.google.com/file/d/0B4HO5r4WOpdzbTJDSUttMmdRMHM/view> [Accessed September 2016].

\section{9-tinghnhfi unfįlnn qhunupuntiph

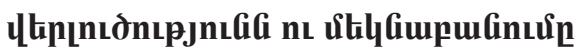

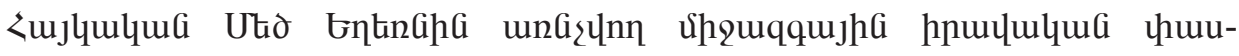

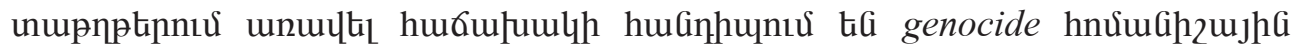

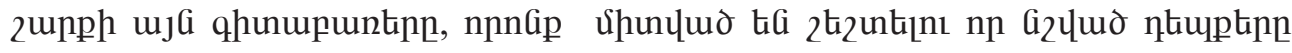

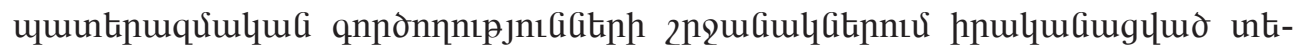

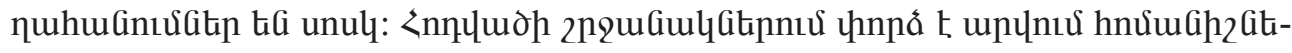




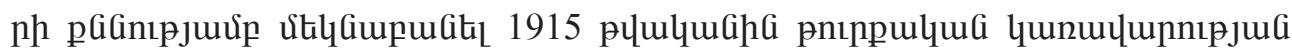

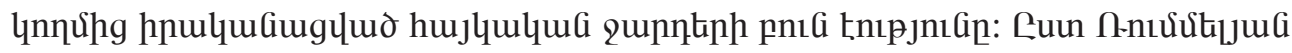

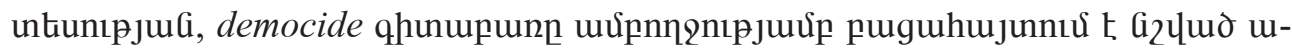

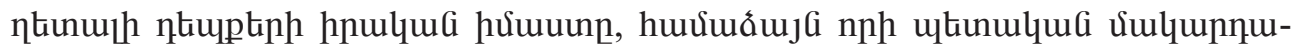

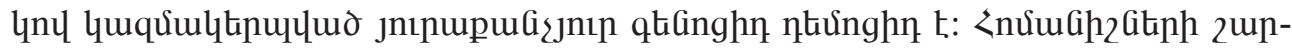

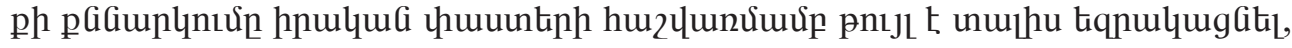

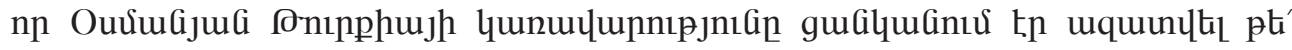

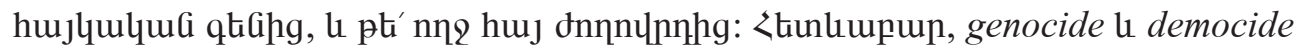

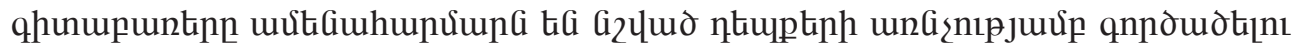
unnưnu: 